\title{
PENGARUH INTENSITAS BIMBINGAN ORANG TUA, SARANA PRASARANA BELAJAR, DAN MOTIVASI BELAJAR TERHADAP HASIL BELAJAR SISWA DENGAN VARIABEL KONTROL STATUS SOSIAL EKONOMI ORANG TUA SISWA
}

\section{(SURVEY PADA MATA PELAJARAN IPS DI MTS ASH-SHIDDIQIYYAH CEMPAKA KECAMATAN PLUMBON KABUPATEN CIREBON)}

\author{
${ }^{1}$ Lindawati, ${ }^{2}$ Mokhammad Wahyudin, ${ }^{3}$ Leni Maryani
}

Email : wati linda13@yahoo.co.id

\begin{abstract}
Problems in this research is less maximal result of learning student of MTs Ashshiddiqiyyah Cempaka District Plumbon of Cirebon Regency in learning process at school; As for the cause is allegedly influenced by the low intensity of parental guidance, learning infrastructure facilities and student learning motivation. The purpose of this study is to determine the effect of the intensity of parental guidance, learning infrastructure, and learning motivation on student learning outcomes with a variable control of the socio-economic status of students' parents. The influence of students' motivation on student learning outcomes in students who have parents with high socioeconomic status and low socioeconomic status. The research method used is survey method Data collection is done through questionnaires. In this study the population is the students of MTs Ash-shiddiqiyyah Cempaka District Plumbon Cirebon Regency as many as 80 people. Data analysis using path analysis. The results of research conducted by researchers obtained by the results there are influences: 1. Intensity of parent guidance of students to the motivation to learn students who have high-status socioeconomic status is lower than the low socioeconomic status; 2. The means of learning to learn the motivation of students who have parents of high socioeconomic status higher than low socioeconomic status; 3. Intensity of parent guidance of student to result of student learning having high status of socioeconomic status higher than student having low socioeconomic status; 4. Learning infrastructure for learning outcomes of students with high socioeconomic status are higher than those with low socioeconomic status; 5 . Student learning motivation on student learning outcomes that have high-status socioeconomic status is higher than students who have low socioeconomic status.
\end{abstract}

Keywords; Intensity of parent guidance, learning infrastructure, learning motivation, learning result, socioeconomic status.

\section{ABSTRAK}

Permasalahan dalam penelitian ini adalah kurang maksimalnya hasil belajar Siswa MTs Ashshiddiqiyyah Cempaka Kecamatan Plumbon Kabupaten Cirebon dalam proses pembelajaran di sekolah; Adapun yang menjadi penyebabnya diduga dipengaruhi oleh rendahnya intensitas bimbingan orang tua, sarana prasarana belajar serta motivasi belajar siswa. Tujuan penelitian ini adalah untuk mengetahui pengaruh intensitas bimbingan orang tua, sarana prasarana belajar, dan motivasi belajar terhadap hasil belajar siswa dengan variabel kontrol status sosial ekonomi orang tua siswa. Metode penelitian yang digunakan adalah metode survey Pengumpulan data dilakukan melalui penyebaran angket. Dalam penelitian ini yang dijadikan populasi adalah siswa MTs Ash-shiddiqiyyah Cempaka Kecamatan Plumbon Kabupaten Cirebon sebanyak 80 orang. Analisis data menggunakan analisis jalur. Hasil penelitian dilakukan peneliti diperoleh dengan hasil terdapat pengaruh : 1. Intensitas bimbingan orang tua siswa terhadap motivasi belajar siswa yang memiliki orang tua berstatus sosial ekonomi tinggi lebih rendah dibandingkan dengan status sosial ekonomi rendah; 2. Sarana parasarana belajar terhadap motivasi belajar siswa yang memiliki orang tua bertatus sosial ekonomi tinggi lebih tinggi dibandingkan dengan status sosial ekonomi rendah; 3. Intensitas bimbingan orang 
tua siswa terhadap hasil belajar siswa yang memiliki orang tua berstatus sosial ekonomi tinggi lebih tinggi dibandingkan siswa yang memiliki status sosial ekonomi rendah; 4. Sarana prasarana belajar terhadap hasil belajar siswa yang memiliki orang tua berstatus sosial ekonomi tinggi lebih tinggi dibandingkan siswa yang memiliki status sosial ekonomi rendah; 5. Motivasi belajar siswa terhadap hasil belajar siswa yang memiliki orang tua berstatus sosial ekonomi tinggi lebih tinggi dibandingkan siswa yang memiliki orang tua berstatus sosial ekonomi rendah.

Kata kunci; Intensitas bimbingan orang tua, sarana prasarana belajar, motivasi belajar, hasil belajar, status sosial ekonomi.

\section{PENDAHULUAN}

Hasil belajar merupakan tolak ukur yang pertama untuk mengetahui tingkat keberhasilan seseorang. Oleh karena itu, hasil belajar yang tinggi dapat dikatakan bahwa ia telah berhasil dalam pembelajaran. Hasil belajar siswa dapat dipengaruhi oleh beberapa faktor baik dari diri siswa (faktor intern), maupun dari luar siswa (faktor ekstern).

Proses belajar mengajar dalam kegiatan dilakukan di sekolah dan di luar sekolah. Menurut Sartain (dalam M. Ngalim Purwanto 2011: 28) ada 3 (tiga) lingkungan pendidikan yang mempunyai pengaruh besar dalam menentukan keberhasilan seseorang dalam kegiatan belajar yaitu: lingkungan keluarga, lingkungan sekolah, dan lingkungan masyarakat.

Proses belajar mengajar semakin meminta perhatian di kalangan peminat dan ahli IImu Pendidikan dan Keguruan sedangkan model dan media pembelajaran yang menjadi pengaruh hasil belajar siswa, banyak faktor-faktor lain yang menjadi pendukung tumbuhnya hasil belajar siswa baik faktor intern maupun faktor ekstern dari siswa tersebut. Dari setiap proses belajar atau kegiatan pembelajaran yang dilakukan, tentunya setiap siswa menginginkan nilai atau hasil yang baik.

\section{LANDASAN TEORI}

\section{Hasil Belajar Siswa}

Menurut Nana Sudjana (2006: 22), "Hasil belajar adalah kemampuan-kemampuan yang dimiliki siswa setelah ia menerima pengalaman belajarnya". Sedangkan menurut Howard Kingsley (Aunnurahman 2010: 45), "Hasil belajar ada tiga macam, yakni: a. Ketrampilan dan kebiasaan, b. pengetahuan dan pengertian, c. sikap dan cita-cita. Begitu juga Clark dalam (Slameto 2006: 21), menjelaskan bahwa "Hasil belajar adalah kemampuan keterampilan, sikap dan keterampilan yang diperoleh siswa setelah ia menerima perlakuan yang diberikan oleh guru sehingga dapat mengkonstruksikan pengetahuan itu dalam kehidupan sehari-hari".

Dapat disimpulkan dari beberapa pendapat diatas, bahwa Hasil Belajar adalah hasil dari usaha yang telah dilakukan oleh peserta didik (siswa) dalam proses perubahan tingkah laku yang dinyatakan dalam bentuk pemahaman, penguasaan, penggunaan, dan penilaian 
terhadap sikap nilai, pengetahuan, dan kecakapan dasar, serta perkembangan keterampilan yang lebih memuaskan, setelah mengalami proses pembelajaran.

\section{Intensitas Bimbingan Orang Tua}

Bimbingan adalah bantuan yang diberikan kepada individu dalam membuat pilihanpilihan dan penyesuaian-penyesuaian yang bijaksana. Bantuan itu berdasarkan atas prinsip demokrasi yang merupakan tugas dan hak setiap individu untuk memilih jalan hidupnya sendiri sejauh tidak mencapuri hak orang lain. Kemampuan membuat pilihan seperti itu tidak diturunkan tetapi harus dikembangkan. Bimbingan membantu setiap individu untuk lebih mengenali berbagai informasi tentang dirinya sendri, membantu individu untuk mencapai pemahaman dan pengarahan diri secara maksimal kepada sekolah, keluarga dan masyarakat.

Bimbingan adalah suatu proses teknis yang teratur, bertujuan untuk menolong individu dalam memilih penyelesaian yang cocok terhadap kesukaran yang dihadapinya, dan membuat rencana untuk mencapai penyelesaiaan tersebut, serta memyesuaikan diri terhadap suasana baru yang membawa kepada penyelesaian. Menurut Bimo Walgito mengenai bimbingan adalah bantuan atau pertolongan yang diberikan kepada individu atau sekelompok individu-individu dalam menghindari atau mengatasi kesulitan-kesulitan di dalam kehidupannya, agar individu atau sekumpulan individu-individu itu dapat mencapai kesejahteraan hidupnya.

Dapat disimpulkan bahwa bimbingan yaitu sebagai suatu proses pemberian bantuan kepada individu yang dilakukan secara keseinambungan supaya individu tersebut dapat memahami dirinya sendiri, sehingga dia sanggup mengarahkan dirinya dan dapat bertindak secara wajar, sesuai dengan tuntunan dan keadaan lingkungan sekolah, keluarga, dan masyarakat dan kehidupan pada umumnya.

\section{Sarana dan Prasarana Belajar}

\section{Sarana Belajar}

Menurut Hafidz (2007: 65), "Sarana adalah peralatan dan perlengkapan yang secara langsung dipergunakan dan menunjang proses pendidikan, khususnya proses belajar mengajar, seperti gedung, ruang kelas, meja kursi, serta alat-alat dan media pengajaran". Sedangkan Menurut Ibrahim Bafadal (2003: 2), "Sarana adalah semua perangkatan peralatan, bahan dan perabot yang secara langsung digunakan dalam proses pendidikan di sekolah". Sejalan dengan pendapat tersebut, Wahyuningrum (2004: 5), berpendapat bahwa sarana pendidikan adalah "Segala fasilitas yang diperlukan dalam proses pembelajaran, yang dapat meliputi barang bergerak maupun barang tidak bergerak agar tujuan pendidikan tercapai". 
Dapat disimpulkan dari beberapa pendapat di atas, bahwa sarana belajar adalah segala fasilitas bisa berupa peralatan, bahan dan perabot yang langsung dipergunakan dalam proses belajar di sekolah. Tentunya semua prasarana dan sarana pendidikan harus dikelola dengan baik.

\section{Prasarana Belajar}

Menurut Tim Dosen (2011: 51), "Prasarana adalah segala sesuatu yang erat kaitannya dengan kondisi tanah, bangunan dan perabotan yang menjadi penunjang terlaksananya proses pendidikan". Sedangkan menurut Hafidz (2007: 65), "Prasarana adalah fasilitas yang tidak langsung menunjang jalannya proses pendidikan atau pengajaran, seperti halaman, kebun, taman sekolah, jalan menuju sekolah, tetapi jika dimanfaatkan secara langsung untuk proses belajar mengajar, seperti taman sekolah". Bagitu juga Menurut Mulyasa (2006: 43), "Prasarana adalah sesuatu yang berkaitan dengan kriteria minimal tentang ruang belajar, tempat berolah raga, tempat beribadah, perpustakaan, laboratorium, bengkel kerja, serta sumber belajar lain, yang diperlukan untuk menunjang proses pembelajaran, termasuk penggunaan teknologi informasi dan komunikasi".

Dapat disimpulkan dari beberapa pendapat di atas, bahwa pengertian prasarana sangat erat kaitannya dengan kondisi tanah berkaitan dengan status kepemilikan tanah yang menjadi tempat pendidikan, bangunan berkaitan dengan kondisi gedung sekolah, ruangan kelas, tempat beribadah, perpustakaan, laboratorium, bengkel kerja, serta sumber belajar lain.

\section{Motivasi Belajar}

Istilah motivasi berasal dari kata motif yang dapat diartikan sebagai kekuatan yang terdapat dari dalam individu, yang menyebabkan individu tersebut bertindak atau berbuat. Hamzah B. Uno (2012: 9) mengatakan bahwa motivasi merupakan suatu dorongan yang timbul oleh adanya rangsangan dari dalam maupun dari luar sehingga seseorang berkeinginan untuk mengadakan perubahan tingkah laku atau aktifitas tertentu yang lebih baik dari sebelumnya.

Jadi di dalam proses belajar motivasi sangat diperlukan sebab seseorang yang tidak mempunyai motivasi dalam belajar akan terhambat untuk melakukan aktifitas belajar. Hal ini merupakan bukti bahwa sesuatu yang akan dikerjakan itu berpengaruh terhadap kebutuhannya. Seseorang yang mempunyai motivasi yang kuat dapat mencapai apa yang dia inginkan untuk menjadi suatu kebanggaan.

Pengertian motivasi menurut Sartain (dalam M. Ngalim Purwanto 2011: 60) mengatakan bahwa motivasi merupakan suatu peryataan yang kompleks di dalam suatu organisme yang mengarahkan tingkah laku terhadap suatu tujuan (goal) atau perangsang (incentive). Sedangkan Wahonosumidjo (dalam Hamzah B. Uno 2012: 8) mengatakan bahwa motivasi merupakan dorongan dan kekuatan dalam diri seseorang untuk melakukan tujuan tertentu 
yang ingin dicapainya. Sedangkan Hamalik (dalam Aunurrahman 2009: 114) motivasi adalah suatu perubahan energi di dalam pribadi seseorang yang ditandai dengan timbulnya efektif (perasaan dan reaksi untuk mencapai tujuan).

Berdasarkan pendapat para ahli di atas, menyimpulkan bahwa motivasi merupakan suatu dorongan atau kekuatan dari dalam diri maupun dari luar untuk melakukan suatu perubahan tingkah laku atau aktifitas yang lebih baik dari keadaan sebelumnya untuk mencapai tujuan tertentu.

\section{Status Sosial Ekonomi Orang Tua Siswa}

Status sosial ekonomi berasal dari tiga kata yang memiliki makna yang berbeda-beda yaitu:

1. Status adalah penempatan orang pada suatu jabatan tertentu

2. Sosial adalah sekumpulan hak dan kewajiban yang dimiliki seseorang manusia sebagai makhluk sosial

3. Ekonomi adalah berasal dari kata ekos dan nomos yang berarti rumah tangga, yang secara harfiah keadaan rumah tangga.

Menurut Sitorus (2000), status sosial ekonomi merupakan kedudukan seseorang di masyarakat, dimana didasarkan pada pembeda masyarakat ke dalam kelas-kelas secara vertikal, yang diwujudkan dengan adanya tingkatan masyarakat dari yang tinggi ke yang lebih rendah dengan mengacu pada pengelompokan menurut kekayaan kelas sosial biasa digunakan hanya untuk lapisan berdasarkan unsur ekonomis.

Menurut Sumardi (2011), Status sosial ekonomi adalah suatu kedudukan yang diatur secara sosial dan menempatkan seseorang pada posisi tertentu dalam masyarakat, pemberian posisi itu disertai pula dengan seperangkat hak dan kewajiban yang harus dimainkan oleh orang yang membawa status tersebut.

Menurut W.S Winke (1991) menyatakan bahwa pengertian status sosial ekonomi mempunyai makna suatu keadaan yang menunjukan pada kemampuan financial keluarga dan perlengkapan material yang dimiliki.

Status sosial ekonomi berasal dari tiga buah kata yang memiliki makna yang berbedabeda. status adalah penempatan orang pada suatu jabatan tertentu sedangkan status sosial adalah sekumpulan hak dan kewajiban yang dimiliki seseorang manusia sebagai makluk sosial dalam masyarakatnya sedangkan Ekonomi adalah berasal dari kata ekos dan nomos yang berarti rumah tangga. Yang secara harfiah keadaan rumah tangga.

Berdasarkan pendapat para ahli diatas, maka dapat disimpulkan bahwa Status sosial ekonomi adalah kondisi yang menggambarkan kedudukan seseorang atau keluarga dalam masyarakat berdasarkan kondisi kehidupan ekonomi atau kekayaan. Hal ini membuktikan betapa dominannya faktor kehidupan ekonomi seseorang dalam menentukan status sosial, walaupun kita sadari bahwa status sosial banyak dipengaruhi oleh unsur lain, seperti 
pendidikan keturunan dan jabatan di mana unsur-unsur tersebut juga akan dapat mempengaruhi kehidupan.

\section{METODE PENELITIAN}

\section{Subjek Penelitian}

Dalam penelitian ini variabel yang diteliti terdiri dari tiga variable bebas (Independent Variabele), variabel kontrol (Variabele control) dan variabel terikat (Dependen Variabele). Variabel bebas terdiri dari intensitas bimbingan orang tua $\left(X_{1}\right)$, sarana prasarana belajar $\left(X_{2}\right)$ motivasi belajar $(X 3)$ dan variabel kontrol status sosial ekonomi orang tua $(Z)$, sedangkan variabel terikatnya adalah hasil belajar siswa $(\mathrm{Y})$.

Penelitian ini dilakukan di MTS Ash-Shiddiqiyyah Cempaka Kecamatan Plumbon Kabupaten Cirebon dengan pertimbangan bahwa kemampuan akademis siswa di sekolah ini cenderung bervariasi sehingga memungkinkan untuk memperoleh banyak informasi yang kaya makna.

\section{Metode Penelitian}

Berdasarkan permasalahan yang akan diteliti maka metode yang digunakan dalam penelitian ini adalah metode survey.

\section{Desain dan Jenis Penelitian}

Berdasarkan metode yang digunakan, penelitian ini merupakan penelitian survei yaitu penelitian yang dilakukan pada ukuran populasi besar maupun kecil tetapi data yang dipelajari merupakan data dari sampel yang terdapat pada populasi tersebut.

\section{Populasi, Sampel dan Tekhnik Sampling}

\section{Populasi}

Populasi dalam penelitian ini adalah seluruh siswa-siswi di MTS Ash-Shiddiqiyyah Cempaka Kec. Plumbon Kab. Cirebon tahun ajaran 2017 - 2018 yang berjumlah 80 siswa. Berikut ini rincian populasi penelitian.

\section{Sampel}

Dalam penelitian ini semua populasi dijadikan sampel dalam penelitaian dikarenakan jumlah populasi siswa 80 .

\section{Alat pengumpulan data}

Angket yaitu daftar pernyataan yang diberikan kepada orang lain dan bersedia memberikan respon sesuai dengan permintaan pengguna.

\section{Uji instrument}

Langkah awal analisa data berupa menguji validitas dan reliabilitas instrumen. Uji validitas dan reliabilitas instrumen dilakukan dengan tujuan untuk mengetahui apakah instrumen tersebut layak untuk digunakan sebagai alat pengumpul data atau tidak. 


\section{Teknik Analisis Data}

Sebelum mengolah data, penulis memeriksa kelengkapan angket terlebih dahulu, untuk mengecek jumlah angket yang terkumpul kembali serta kelengkapan jawaban dari responden, kemudian dilakukan pengolahan terhadap data yang diperoleh dari intrumen angket dan menganalisisnya melalui langkah-langkah sebagai berikut.

\section{Analisis Deskriptif}

Untuk mengetahui gambaran intensitas bimbingan orang tua, sarana prasarana belajar, motivasi belajar terhadap hasil belajar siswa dengan variabel kontrol ststus sosial ekonomi orang tua di MTS Ash-Shiddiqiyyah Cempaka Kab. Cirebon.

\section{Pengujian Prasyaratan Analisis}

Data keempat variabel penelitian ini selanjutnya dianalisis dengan menggunakan analisis statistik inferensial melalui teknik regresi sederhana dan regresi ganda. Sebelum analisis data pengujian hipotesis terlebih dahulu dilakukan uji persyaratan analisis yakni uji normalitas dan uji multikolinieritas, uji heterokedastisitas dan uji auto korelasi.

\section{Metode Analisis Data}

Dalam penelitian ini teknik yang diambil yaitu analisis jalur dikarenakan penelitian ini variabelnya lebih dari satu.

\section{Analisis Jalur (Path Analysis)}

Analisis jalur (path analysis) ini digunakan untuk memprediksi pengaruh variabel $\mathrm{X}_{1}$, $\mathrm{X}_{2}$, dan $\mathrm{X}_{3}$, terhadap variabel $\mathrm{Y}$.

\section{PEMBAHASAN}

\section{Gambaran Variabel}

1. Intensitas bimbingan orang tua yang berstatus sosial ekonomi tinggi lebih tinggi presentasenya dari pada intensitas bimbingan orang tua yang berstatus sosial ekonomi rendah.

2. Sarana prasarana belajar siswa yang memiliki orang tua berstatus sosial ekonomi tinggi lebih tinggi presentasenya dari pada sarana prasarana yang memiliki orang tua berstatus sosial ekonomi rendah.

3. Motivasi belajar siswa yang memilki orang tua berstatus sosial ekonomi tinggi lebih tinggi presentasenya dari pada motivasi belajar yang berstatus sosial ekonomi rendah.

4. Hasil belajar siswa yang memiliki orang tua berstatus sosial ekonomi tinggi lebih rendah presentasenya dari pada hasil belajar siswa yang berstatus sosial ekonomi rendah. 


\section{Pengaruh Antar Variabel}

1. Terdapat pengaruh intensitas bimbingan orang tua terhadap motivasi belajar siswa. Pengaruh intensitas bimbingan orang tua terhadap motivasi belajar siswa yang memiliki orang tua berstatus sosial ekonomi tinggi lebih rendah dibandingkan siswa yang memiliki orang tua berstatus sosial ekonomi rendah $0,844<0,868$.

2. Terdapat pengaruh sarana prasarana belajar siswa terhadap motivasi belajar siswa. Pengaruh sarana prasarana belajar siswa terhadap motivasi belajar siswa yang memiliki orang tua berstatus sosial ekonomi tinggi lebih tinggi dibandingkan siswa yang memiliki orang tua berstatus sosial ekonomi rendah 0,903 0,755.

3. Terdapat pengaruh intensitas bimbingan orang tua terhadap hasil belajar siswa. Pengaruh intensitas bimbingan orang tua terhadap hasil belajar siswa yang memiliki orang tua berstatus sosial ekonomi tinggi lebih tinggi dibandingkan siswa yang memiliki orang tua berstatus sosial ekonomi rendah 0,880 >0,822.

4. Terdapat pengaruh sarana prasarana belajar siswa terhadap hasil belajar siswa. Pengaruh sarana prasarana belajar siswa terhadap hasil belajar siswa yang memiliki orang tua berstatus sosial ekonomi tinggi lebih tinggi dibandingkan siswa yang memiliki orang tua berstatus sosial ekonomi rendah 0,948 > 0,759.

5. Terdapat pengaruh motivasi belajar siswa terhadap hasil belajar siswa. Pengaruh motivasi belajar siswa terhadap hasil belajar siswa yang memiliki orang tua berstatus sosial ekonomi tinggi lebih tinggi dibandingkan siswa yang memiliki orang tua berstatus sosial ekonomi rendah 0,811 >0,628.

\section{SIMPULAN}

1. Terdapat pengaruh intensitas bimbingan orang tua terhadap motivasi belajar siswa. Pengaruh intensitas bimbingan orang tua terhadap motivasi belajar siswa yang memiliki orang tua berstatus sosial ekonomi tinggi lebih rendah dibandingkan siswa yang memiliki orang tua berstatus sosial ekonomi rendah 0,844 $<0,868$.

2. Terdapat pengaruh sarana prasarana belajar siswa terhadap motivasi belajar siswa. Pengaruh sarana prasarana belajar siswa terhadap motivasi belajar siswa yang memiliki orang tua berstatus sosial ekonomi tinggi lebih tinggi dibandingkan siswa yang memiliki orang tua berstatus sosial ekonomi rendah 0,903 > 0,755.

3. Terdapat pengaruh intensitas bimbingan orang tua terhadap hasil belajar siswa. Pengaruh intensitas bimbingan orang tua terhadap hasil belajar siswa yang memiliki orang tua berstatus sosial ekonomi tinggi lebih tinggi dibandingkan siswa yang memiliki orang tua berstatus sosial ekonomi rendah 0,880 > 0,822. 
4. Terdapat pengaruh sarana prasarana belajar siswa terhadap hasil belajar siswa. Pengaruh sarana prasarana belajar siswa terhadap hasil belajar siswa yang memiliki orang tua berstatus sosial ekonomi tinggi lebih tinggi dibandingkan siswa yang memiliki orang tua berstatus sosial ekonomi rendah 0,948 > 0,759.

5. Terdapat pengaruh motivasi belajar siswa terhadap hasil belajar siswa. Pengaruh motivasi belajar siswa terhadap hasil belajar siswa yang memiliki orang tua berstatus sosial ekonomi tinggi lebih tinggi dibandingkan siswa yang memiliki orang tua berstatus sosial ekonomi rendah $0,811>0,628$.

\section{DAFTAR PUSTAKA}

Adi, Purnomo.2003.Lokakarya Fasilitas Olahraga.Jakarta:PT Gramedia Pustaka Utama

Arikunto Suharsinih. (2010). Prosedur Penelitian. Jakarta : Rineka Cipta

Aunnurahman. (2009). Belajar Dan Pembelajaran. Bandung: Alfabeta.

Bafadal. I. (2009). Pengelolaan Perpustakaan Sekolah. Jakarta: Bumi Aksara.

Departemen Pendidikan Nasional, (2002). Kamus Besar Bahasa Indonesia Edisi Ketiga. Jakarta : Balai Pustaka.

Dimyati, Dkk. (2009). Belajar Dan Pembelajaran. Jakarta : Rineka Cipta.

Djamarah, B.S \& Aswan Zain (2010). Strategi Belajar Mengajar. Jakarta : Rineka Cipta.

Herabudin. (2009). Administrasi dan Supervisi pendidikan. Bandung: Pustaka Setia.

Mulyasa. E. 2006. Kurikulum Yang Disempurnakan. Bandung: Remaja Krosda Karya.

Munadi. Y. (2008). Media Pembelajaran Sebuah pendekatan Baru. Jakarta: Gaung Persada Press.

Moh. Surya. (2004). Psikologi Pembelajaran dan Pengajaran. Bandung: Pustaka Alfabeta

Prawiradilaga Salma Dewi. (2007). Prinsip Desain Pembelajaran. Jakarta:Kencana.

R. Ibrahim dan Nana Syaodih S. (2003). Perencanaan Pengajaran. Jakarta: Rineke Cipta.

Riduwan. (2011). Dasar-Dasar Statistika. Bandung : Alfabeta.

Sagala, Syaiful. (2006). Konsep dan Makna Pembelajaran Untuk Membantu Memecahkan Problematika Belajar dan Mengajar. Bandung : CV Alfabeta.

Sanjaya, W. (2010). Strategi Pembelajaran Berorientasi Standar Proses Pendidikan. Jakarta : Kencana Preneda Media Group.

Slameto. (2003). Belajar dan Faktor-faktor Yang Mempengaruhinya. Jakarta: Rineka Cipta.

Sopiatin, Popi. (2010). Manajemen Belajar Berbasis Kepuasan Siswa.Bogor. Ghalia Indonesia.

Sudjana, N. (2010). Dasar-Dasar Proses Belajar Mengajar. Bandung: Sinar Baru Algensindo Offset. 
Sudjana, N. (2006). Penilaian Hasil Belajar Proses Belajar Mengajar. Bandung: PT Remaja Rosdakarya Offset

Sugiyono. (2012). Metode Penelitian Pendidikan Pendekatan kuantitatif, Kualitatif, dan R\&D. Bandung : Alfabeta.

Suryosubroto. (2002). Proses Belajar Mengajar Disekolah. Jakarta: Rineka Cipta.

Susilo Joko Muhammad. (2007). Kurikulum Tingkat Satuan Pendidikan. Yogyakarta: Pustaka Pelajar Offset.

\section{Skripsi, Tesis, Artikel, Jurnal dan Sumber lainnya:}

Ari Diaz, http://www.tribunkaltim.com

Amirin, M.T (2011). Pengertian Sarana dan Prasarana Pendidikan. Tatangmanguny. Wordspress. Com.

http://id.shvoong.com/writing-and-speaking/presenting/2106962-pengertian-sarana-danprasarana/\#ixzz2OjppCKAa

Kusmanto (2012). Pengaruh Kompetensi Pedagogik Guru dan Intensitas Bimbingan Orang Tua Terhadap Motivasi Belajar Dan Implikasinya Terhadap Prestasi Belajar Siswa. Survei Pada Siswa SMP Negeri se-Kecamatan Salem Kabupaten Brebes. Tesis pada Pascasarjana Universitas Kuningan: Tidak diterbitkan.

Lindawati, (2013). Pengaruh Sarana Dan Prasarana Terhadap Prestasi Belajar Siswa Pada Mata Pelajaran Ekonomi. Survey diMadrasah Aliyah Mafatihul Huda Kabupaten Cirebon Dan Smk Kandang Haur Indramayu. Skripsi pada FKIP Unswagati Cirebon: Tidak diterbitkan.

Mardi, (2010). Pengaruh Status Sosial Ekonomi Orang Tua Dan Motivasi Belajar Terhadap Prestasi Belajar Siswa Smp Negeri 2 Losari Kabupaten Brebes. Tesis pada Pascasarjana Universitas Kuningan. Tidak diterbitkan

Mokhammad Wahyudin,(2016). Pengaruh intensitas bimbingan orang tua dan sarana prasarana terhadap motivasi belajar siswa serta implikasinya pada prestasi belajar siswa (survey pada mata pelajaran kewirausahaan di smk ulil albab depok kabupaten cirebon). Tesis pada Pascasarjana Universitas Kuningan. Tidak diterbitkan

Pengolahan data SPSS v.17 terdapat di:

http//www.spssindonesia.com/2014/01/pengolahan data. 24 mei 2016. 21.15.

Rutesih, (2011). Pengaruh Status Ekonomi Keluarga Dan Intensitas Bimbingan Orang Tua Terhadap Perilaku Belajar Dan Implikasinya terhadap Hasil Belajar Siswa. Survei Pada Smp Negeri 1 Sukagumiwang Kabupaten Indramayu. Tesis pada Pascasarjana Universitas Kuningan: Tidak diterbitkan.

Reddy Zaki Oktama, (2013), Pengaruh Kondisi Sosial Ekonomi Terhadap Tingkat Pendidikan Anak Keluarga Nelayan Di Kelurahan Sugihwaras Kecamatan Pemalang Kabupaten Pemalang. Skripsi pada Fakultas Ilmu Sosial Universitas Negeri Semarang. Diterbitkan

Skripsi Siti Novy Pebriyanty, (2014) Hubungan Intensitas Bimbingan Orang tua dengan Hasil Belajar Siswa di MI Nur As-Sholihat Lengkong Wetan Serpong. 
Daryanto, (2005). Evaluasi Pendidikan, Jakarta : Rineka IImu

Ennis. H. Robert. 1989. "Critical Thinking and Subject Specificity : Clarification and Needed Researh”. Journal Educational Resercher 18 (3). 4-10.

Fisher, Alec (2008). Chritical Thingking An Introduction, Terjemahan, Bandung Penerbit Erlangga

Gardner, Howard. 2003. Kecerdasan Majemuk, Teori dalam Praktek. Batam. Interaksara.

Gordon, Thomas, (1996). Guru yang Efektif, Jakarta, Penerbit PT Raja Grafindo Persada

Moh. Uzer Usman, (2007), Menjadi Guru Profesional, Bandung: Remaja Rosdakarya

Mohamad Surya, (2004). Psikologi Pembelajaran dan Pengajaran, Bandung: Pustaka Bani

Quraisy Muhibbin Syah, (2006). Psikologi Pendidikan dengan Pendekatan Baru, Bandung:

Remaja Rosdakarya

Noeng Muhadjir, (1992). Pengukuran Kepribadian, Yogyakarta: Rake Sarkih

Oemar Hamalik, (2006). Pendidikan Guru berdasarkan Pendekatan Komptensi, Jakarta: Bumi Aksara.

Paul. Richard. Binker. Weil Daniel. (1990). Critical Thingking Handbook : a guide for remodelling Lesson plans in Language art, Sosial Studies, and Science. Foundation for critical thinking Sonoma state University. Rohnet Park, CA 94928.

Raths. E. Louis. e. al. (1986). Teaching For Thinking, Theory, Strategies, and activities for Classroom. Second Edition.Teacher College, Columbia University. New York

Slameto, (2003). Belajar dan Faktor-faktor yang Mempengaruhinya. Jakarta: Rineka Cipta

Suparno, P. (2004). Teori inteligensi gand dan aplikasi di sekolah (cara menerapkan teori multiple intelligences Howard gardner). Yogyakarta: Kanisius.

Suharmi Arikunto, (2010). Prosedur Penelitian : Suatu Pendekatan Praktik, Jakarta: Rineka Cipta

Tabrani Rusyan, (1999). Pendekatan Dalam Proses Belajar Mengajar, Bandung: PT. Remaja Rosdakarya. 